\title{
Secondary Equity Offer Announcements and Share Returns at Nairobi Securities Exchange, Kenya
}

\author{
Kenneth Marangu ${ }^{1}$, Stephen Muathe ${ }^{1} \&$ Lucy Mwangi $^{1}$ \\ ${ }^{1}$ School of Business, Kenyatta University, Nairobi, Kenya \\ Correspondence: Kenneth Marangu, School of Business, Kenyatta University, Nairobi, Kenya.
}

Received: July 2, 2019

doi:10.5430/ijfr.v10n6p95
Accepted: August 9, 2019

Online Published: August 18, 2019

URL: https://doi.org/10.5430/ijfr.v10n6p95

\begin{abstract}
This paper empirically analyzes the effect of secondary equity offer announcements on share returns at Nairobi Securities Exchange in Kenya by investigating the information content of the announcements and ascertaining whether the release of financial information in the capital market affects share returns. An event study employing the market return model determined share returns of 52 bonus issues and 28 rights issues announced between January 2006 and December 2015. The study established that secondary equity offer announcements had a significant and positive effect on share returns and that rights issues witnessed higher share returns when compared to bonus issues during the twenty-day event period. This study recommends management of Nairobi Securities Exchange listed companies to raise capital through secondary equity offers, as companies will increase their market capitalization. Investors on Nairobi Securities Exchange are encouraged to participate in secondary equity offers because they will earn positive share returns and increase their wealth. Existing shareholders should fully participate in rights issues because they will forgo positive share returns if they renounce their rights. Capital Markets Authority and Nairobi Securities Exchange should encourage more listed companies to raise capital through secondary equity offers, as this is advantageous to companies and investors.
\end{abstract}

Keywords: event study, Nairobi Securities Exchange, secondary equity offer announcements, share returns

\section{Introduction}

\subsection{Share Returns}

The investment principle as espoused by Goetzmann (2000) postulates that investor key objectives are driven by the need to receive a steady stream of income and cash flows as well as growing the size of their investment. Consequently, investors seek to earn returns to finance immediate cash requirements, maintain a margin of safety to fund other viable investments and meet non-foreseen financial obligations. Investors are also very keen on increasing the value of their initial investment during the investment-holding period.

Return on an investment compensates investors for the opportunity cost arising from the time value of money, the reduction in the purchasing power of money and the risk that the amount of money invested will fail be recouped at the end of the investment period (Reilly \& Brown, 2011). The summation of these three components, referred to as the required rate of return, is the minimum rate of return that an investor accepts from an investment as compensation for deferring present consumption.

Shares are a very common, popular and acceptable class of investment among investors globally because they offer investors an opportunity to earn returns. Investors in the shares of a company earn share returns through annual dividends received as a share of profitability and through capital gains that are realized when market share prices increase over time (Wilcox \&Fabozzi, 2013).

\subsection{Secondary Equity Offers}

A capital market performs a very fundamental function in an economy of transferring wealth from resource surplus households and institutions to resource deficit institutions. A capital market contributes to economic growth and development in a country through financial development by availing institutions an opportunity to raise capital to finance viable investments, which have the overall effect of increasing company market value and investor wealth (Owusu \& Kuwornu, 2011). 
A securities exchange is an integral component of the capital market that facilitates trading of financial assets and is important in an economy because it is an indicator of the level of economic performance (Kirui, Wawire \& Onono, 2014). Kenya has only one capital market namely, Nairobi Securities Exchange which plays a vital role in the growth of Kenya's economy by encouraging savings and investment as well as assisting local and international companies to access capital.

A secondary equity offer entails issuance of new additional shares in a securities exchange after an initial public offer and encompasses issuing of shares to existing shareholders, new shareholders or a combination of existing and new shareholders. The most common classes of secondary equity offers at Nairobi Securities Exchange are bonus issues and rights issues.

A bonus issue also referred to as a script dividend entails issuance of free additional new shares to existing shareholders. Bonus issues are popular as an alternative to cash dividends and increasing dividend payout and are attractive to companies with cash flow constraints and a shareholder base that demands consistent income. A rights issue is an invitation offered to existing shareholders to acquire additional shares in a company in proportion to their existing shareholding. The rights issue price is generally lower than the prevailing market prices, which allows shareholders to transfer and sell their rights to potential investors on the securities exchange (Wright \& Sylla, 2013).

\subsection{Share Returns of Secondary Equity Offers}

In securities exchanges, secondary equity offer announcements can have a neutral, positive or negative effect on share returns. Neutral effect implies secondary equity offer announcements do not affect share prices. Positive effect infers that secondary equity offer announcements are a positive market signal that results to an increase in share prices while negative effect is an indicator that secondary equity offer announcements are a negative market signal that results to a decrease in share prices.

According to the efficient market hypothesis, when investors obtain new information in the market, they react differently such that some investors perceive the information to be good news while other investors react negatively to the same set of information. Therefore, in a capital market, investor reactions do not follow any particular pre-determined pattern or trend and thus the announcement of secondary equity offers is expected to have a neutral effect on share returns (Eitman, Stonehill \& Moffet, 2013).

The random walk theory complements the efficient market hypothesis and stipulates that in capital markets, share prices follow a random walk trend and are independent of each other. This proposition is anchored on the premise that investors in shares react differently and instantaneously to any new information that is available in the market, which eliminates the likelihood of using public information to earn above normal share returns (Reilly \& Brown, 2011).

Jensen and Meckling (1976) propose that shareholders as principals ensure that management as agents always act in the best interest of shareholders by ensuring that part of executive management compensation is in the form of shares and share options. Therefore, equity capital raising is construed by capital markets to be good news because management are not expected to make decisions that will jeopardize the interests of shareholders because they dread losing out on their performance based remuneration. Therefore, according to the agency cost theory, the announcement of secondary equity offers is expected to have a positive effect on share returns.

Myers and Majluf (1984) posit that when management make investment and financing decisions, they are privy to more information about a company's market value than existing shareholders and potential investors. When the capital market significantly undervalues a company's assets and management opines that the dilution effect on existing shareholders will be greater than any gains made by undertaking positive net present value projects, management does not approve investments that require equity financing. According to the information asymmetry theory, secondary equity offers are an indicator of overvalued shares and thus the announcement of secondary equity offers is expected to have a negative effect on share returns.

Empirical literature on the effect of secondary equity offer announcements on share returns in developed and emerging capital markets presents mixed results because it reports neutral, positive and negative share returns. Hess and Frost (1982) observed neutral share returns, Lerskullawat (2011) found negative share returns and Huang (2012) reports positive share returns at New York Stock Exchange, Stock Exchange of Thailand and Shanghai Stock Market respectively. Miglani (2011) posits that developed, emerging and developing capital markets differ in terms of assets, liquidity, size, activity and risks and thus secondary equity offer announcements are likely to have different effects on share returns in different capital markets.

At Nairobi Securities Exchange, studies on the effect of rights issue announcements on share returns report mixed 
results. Ogada (2014) and Mariko and Theuri (2016) observed neutral share returns, Olesaaya (2010) and Otieno (2014) reported negative share returns while Ndungu (2014) and Kithinji, Oluoch and Mugo (2014) found positive share returns. Kamanja (2014), Ndegwa and Kiweu (2013) and Mbui (2016) report that bonus issue announcements had a positive effect on share returns at Nairobi Securities Exchange.

Analysis of small sample sizes, employment of very short data series and inadequate statistical procedures could have contributed to the reporting of non-uniform findings on the Nairobi Securities Exchange. This study addressed these shortcomings by including bonus issues and rights issues to attain a large sample size, employing a ten-year study period to extend the data series and performing diagnostic tests to improve data management statistical procedures, which added rigor and robustness to the study findings.

Based on the findings reported by studies on the Nairobi Securities Exchange, some companies that raised capital through secondary equity offers increased their market value while others decreased their market value. Similarly, some investors who participated in secondary equity offers increased their wealth while others decreased their wealth. Given historical trends, secondary equity offers will continue to be a popular capital raising option among companies listed on Nairobi Securities Exchange but management are not certain whether companies will increase their market value and investors are not sure whether they will increase their wealth if they participate in the future secondary equity offers. It is therefore imperative that management and investors are availed with information on the effect of secondary equity offer announcements on share returns in a developing capital market such as the Nairobi Securities Exchange so that they can improve their financial and investment decision-making.

\subsection{Study Objectives and Hypotheses}

The general objective of this study was to investigate the effect of secondary equity offer announcements on share returns at Nairobi Securities Exchange, Kenya. The specific objectives of this study were as follows:

a) To establish the effect of bonus issue announcements on share returns at Nairobi Securities Exchange, Kenya

b) To determine the effect of rights issue announcements on share returns at Nairobi Securities Exchange, Kenya

c) To examine the effect of bonus issue and rights issue announcements on share returns at Nairobi Securities Exchange, Kenya

The study tested the following hypotheses aligned with the specific objectives:

$\mathrm{H}_{01}$ : Bonus issue announcements do not significantly affect share returns of secondary equity offers

$\mathrm{H}_{02}$ : Rights issue announcements do not significantly affect share returns of secondary equity offers

$\mathrm{H}_{03}$ : Bonus issue and rights issue announcements do not significantly affect share returns of secondary equity offers

\section{Literature Review}

\subsection{Theoretical Literature Review}

Fama and French (1992) note that a capital market is efficient if the prevailing market prices of shares fully and correctly reflect all fundamental information expected to affect share prices. Fama (1998) proposed three different sets of information in the market namely past information, publicly available information and private information. The semi strong form of market efficiency contends that the current market price of a company's shares fully incorporates all information that is available in the public domain. Since capital market regulators require listed companies to announce publicly secondary equity offers, the efficient market hypothesis hypothesizes that secondary equity offer announcements have a neutral effect on share returns.

Jensen and Meckling (1976) propose that shareholders as principals ensure that management as agents always act in the best interest of shareholders by ensuring that part of executive management compensation is in the form of shares and share options. Therefore, when a company raises capital through secondary equity offers, the capital market construes this to be good news because management are not expected to make decisions that will endanger the interests of shareholders because if they do so, management will have to forfeit their performance based remuneration. Therefore, the agency cost theory hypothesizes that secondary equity offer announcements have a positive effect on share returns.

Kraus and Litzenberger (1973) point out that management make decisions on capital structure by determining the amounts of equity and debt capital that a company will employ to attain an optimal capital structure. Myers (1984) observed that debt financing is advantageous because of the tax shield advantage that debt has over equity. Management is expected to set a target debt to equity ratio that will optimize the value of the company and actively seek to employ equity and debt financing sequentially to attain the target or optimal level. Medeiros and Matsumoto 
(2005) argue that when a company raises finance through secondary equity offers, investors assume that management are seeking to attain the optimal capital structure that will maximize the value of the company. Consequently, the static trade off theory hypothesizes that secondary equity offer announcements have a positive effect on share returns.

Myers and Majluf (1984) posit that when management make financing and investment decisions, they are more informed about a company's market value than current shareholders and potential investors. When the market significantly undervalues a company's shares and management opines that the dilution suffered by existing shareholders will be greater than any profit realized by undertaking positive net present value projects, they postpone investments requiring equity financing. Therefore, capital markets view secondary equity offers as overvalued and thus the information asymmetry theory hypothesizes that secondary equity offer announcements have a negative effect on share returns.

Berk and De Marzo (2013) demonstrated that the principle of lemons coined by Akerlof (1970) applies to the equity market by presenting a scenario of a shareholder in a growing company operating in a growing market and offering to sell their entire shareholding. This explains why companies with good growth prospects, strong fundamentals and operating in attractive business segments may opt to finance their operations through debt capital even when equity capital is a better value proposition. Consequently, when a company raises capital through secondary equity offers, this information is perceived to be a negative signal in the capital market, which leads to a decrease in market share prices. Therefore, the adverse selection principle hypothesizes that secondary equity offer announcements have a negative effect on share returns.

\subsection{Empirical Literature Review}

Empirical research confirms that market reaction to secondary equity offer announcements varies in developed, emerging and developing capital markets. According to Agrawal and Mohanty (2012), Finland, Japan, Norway and Switzerland and Sweden reported positive share returns while Australia, Hong Kong, Korea, United Kingdom and United States reported negative returns.

Huang (2012) documents that announcements of secondary equity offers had a positive effect on share returns in Shanghai Stock Exchange in China during the period 1994 to 2009. The study used a sample size of 209, employed the event study methodology and the market model to estimate expected share returns and a twenty-day event window period, which this study adopted. Onclin (2014) reports that rights issue announcements had a negative effect on share returns in the Dutch Securities Market during the period 2001 to 2013. The study used a sample size of 34 and employed the event study methodology and the market model to estimate expected share returns, which this study adopted.

Miglani (2011) reports that rights issue announcements had a positive effect on share returns at Bombay Stock Exchange in India during the period 2005 to 2010. Using a sample size of 32, the study employed the event study methodology and the market model to estimate expected share returns, which this study adopted. Ramesh and Rajumesh (2014) document that rights issue announcements had a positive effect on share returns at Colombo Stock Exchange in Sri Lanka during the period 2008 to 2012. Using a sample of 78 events, the event study methodology and the market model were employed which were both adopted in this study.

Ndungu (2014) documents that rights issue announcements had a positive effect on share returns at Nairobi Securities Exchange during the period 2009 to 2013. The study used a small sample size of eight and a short time period of five years. Otieno (2014) reports that rights issue announcements had a negative effect on share returns at Nairobi Securities Exchange during the period 2007 to 2014. The study used a small sample size of 12 and did not perform diagnostic tests.

Mariko and Theuri (2016) detailed that rights issue announcements had a neutral effect on share returns at Nairobi Securities Exchange during the period 2004 to 2013. The study does not reconcile the high mean abnormal share returns of between 0.66 and 0.73 that had an overall neutral effect. Mbui (2016) established that bonus issue announcements had a positive effect on share returns at Nairobi Securities Exchange during the period 2010 to 2014. The study used a small sample size of five, a short time period of five years and a short event window period of fifteen days.

Miglani (2011) posits that developed and emerging capital markets differ from developing capital markets in terms of assets, liquidity, size, activity and risks and thus secondary equity offer announcements are likely to have different effects on share returns in different capital markets.

Analysis of small sample sizes, employment of very short data series and inadequate statistical procedures could 
have contributed to the reporting of non-uniform findings on the Nairobi Securities Exchange. This study sought to address this research gap and provide management and investors on the Nairobi Securities Exchange with information on the effect of secondary equity offer announcements on share returns so that they can improve their financial and investment decision-making.

\section{Research Methodology}

\subsection{Research Design}

This study investigated the effect of secondary equity offer announcements on share returns at Nairobi Securities Exchange and thus adopted a non-experimental research design. Non-experimental research design was appropriate for this study because the researcher did not control, manipulate or alter the dependent variable and the independent variables, but relied on observation, interactions and interpretation to make conclusions. Kerlinger and Lee (2000) espouse that non-experimental research has a high level of external validity thus implying that the results and findings of a study sample can be generalized to a larger population.

\subsection{Population of the Study}

The target population of this study was 80 secondary equity offers comprising of 52 bonus issues and 28 rights issues announced by companies listed on Nairobi Securities Exchange during the period January 2006 to December 2015. Since the target population of this study was 80 secondary equity offers, which is a small population, this study adopted a census approach. According to Saunders, Lewis and Thornhill (2009), a census approach enhances the validity of the data collected because it includes a complete data set that leads to a high degree of statistical confidence in the study results.

\subsection{Data Analysis}

The announcement of a secondary equity offer was the event of interest while the period of interest covered twenty trading days before and after the announcement of a secondary equity offer. Examining the effect of secondary equity offer announcements on share returns entailed determining actual share returns, determining expected share returns, calculating abnormal share returns and determining the significance of the abnormal share returns using the Brown and Warner (1985) and MacKinlay (1997) methodologies.

To assess the effect of secondary equity offer announcements on share returns, it was essential to posit the relationship between the release of financial information in the capital market and the changes in the market share prices. If secondary equity announcements possessed information content, higher than expected share returns would be associated with good market news and lower than expected share returns would be associated with bad market news.

Actual share returns can be calculated using logarithmic return models and simple return models. Meucci (2012) observes that in empirical finance, logarithmic return models are preferred over simple return models to calculate actual share returns because they are construed as continuously compounded share returns. Continuous compounding of expected $\log$ share returns provides a better guide to the future cumulative share returns. This study therefore adopted the log return model to compute actual share returns as specified by model (1) where the holding period was equated to one trading day at Nairobi Securities Exchange.

$$
\mathrm{ASR}_{\mathrm{it}}=\log \left[\mathrm{P}_{1}-\mathrm{P}_{0}\right] / \log \mathrm{P}_{0}
$$

Where

$\mathrm{ASR}_{\mathrm{it}}=$ Actual share returns of company $_{\mathrm{i}}$ at time ${ }_{\mathrm{t}}$

$\mathrm{P}_{1}=$ Price at the end of the holding period

$\mathrm{P}_{0}=$ Price at the beginning of the holding period

Expected share returns can be calculated using statistical models and economic models. According to MacKinlay (1997), statistical models are preferred over economic models because they assume that share returns are normal and evenly distributed over time. In addition, statistical models have greater flexibility than economic models under conditions where a financial researcher seeks to analyze share returns using the generalized method of moments to remedy autocorrelation and heteroscedasticity in time series data. This study therefore adopted the market return model, which is a statistical model.

According to Brown and Warner (1985), price models and market models can be used to estimate expected share returns. Medeiros and Matsumoto (2005) point out that price models possess intricate econometric issues such as non-stationarity of price series and thus market models are preferred and commonly applied in financial research. 
Two market models commonly employed in financial research to compute share returns are the constant mean return model and the market return model. The market return model has greater ability to detect the effects of an event when compared to the mean return model because it excludes the proportion of share returns related to variation in market returns, which decreases the variance of abnormal share returns.

Whilst the market return model is a single-factor return model, Meucci (2012) highlights that for event studies, the gains realized from employing multi-factor return models are not significant because the additional explanatory power resulting from the inclusion of extra factors to the market return is marginal and yields a minimal decrease in the variance of abnormal share returns. The market return model (2) was therefore used to compute expected share returns and is based on the assumption of a constant and linear relationship between individual share returns and the return on a market index.

$$
\mathrm{ESR}_{\mathrm{it}}=\alpha_{\mathrm{i}}+\beta_{\mathrm{i}} \mathrm{R}_{\mathrm{m}}+\varepsilon_{\mathrm{it}}
$$

Where

$\mathrm{ESR}_{\mathrm{it}}=$ Expected share returns of company $_{\mathrm{i}}$ at time ${ }_{\mathrm{t}}$

$\alpha_{i}=$ Return on share ${ }_{i}$ when there is no change in the market returns

$\beta_{\mathrm{i}}=$ Beta coefficient of company ${ }_{\mathrm{i}}$

$\mathrm{R}_{\mathrm{m}}=$ Return on Nairobi Securities Exchange twenty share index

$\varepsilon_{\text {it }}=$ Zero mean disturbance term/error term

Return on share of company ${ }_{i}$ when there is no change in the market returns denoted as $\alpha_{i}$ was computed using model (3) as follows:

$$
\alpha_{\mathrm{i}}=\mu_{\mathrm{i}}-\beta_{\mathrm{i}} \mu_{\mathrm{m}}
$$

Beta coefficient of company ${ }_{\mathrm{i}}$ denoted as $\beta_{\mathrm{i}}$ was computed using model (4) as follows:

$$
\beta_{\mathrm{i}}=\sum\left[\mathrm{ESR}_{\mathrm{it}}-\mu_{\mathrm{i}}\right]\left[\mathrm{R}_{\mathrm{m}}-\mu_{\mathrm{m}}\right] / \sum\left[\mathrm{R}_{\mathrm{m}}-\mu_{\mathrm{m}}\right]^{2}
$$

Variance $\left[\varepsilon_{\mathrm{it}}\right]$ denoted as $=\sigma^{2}$ eit was computed using model (5) as follows:

$$
\sigma_{\text {git }}^{2}=\sum\left[\mathrm{ESR}_{\mathrm{it}}-\alpha_{\mathrm{i}}-\beta_{\mathrm{i}} \mathrm{R}_{\mathrm{m}}\right]^{2}
$$

Where

$\mu_{\mathrm{i}}=\sum\left[1 / \mathrm{N} * \mathrm{ESR}_{\mathrm{it}}\right]$

$\mu_{\mathrm{m}}=\sum\left[1 / \mathrm{N} * \mathrm{R}_{\mathrm{m}}\right]$

Bollerslev (1986) reports that daily share prices and daily share returns present variable volatility over time thus exhibiting autoregressive conditional heteroscedastic effects. The presence of autoregressive conditional heteroscedasticity in data implies that the estimation of model (2) using the ordinary least squares methodology will be biased and inconsistent. In this regard, if autoregressive conditional heteroscedasticity was to be detected in the time series data set, model (2) was to be re estimated using the generalized autoregressive conditional heteroscedastic models (6) and (7) as follows:

$$
\begin{aligned}
\mathrm{ESR}_{\mathrm{it}} & =\alpha_{\mathrm{i}}+\beta_{\mathrm{i}} \mathrm{R}_{\mathrm{m}}+\varepsilon_{\mathrm{it}} ; \varepsilon_{\mathrm{it}} \sim \mathrm{N}\left(0,2 \sigma_{\mathrm{it}}^{2}\right) \\
\sigma_{\mathrm{it}}^{2} & =\alpha_{\mathrm{i} 0}+\alpha_{\mathrm{il}} \varepsilon_{\mathrm{it}-1}^{2}+\alpha_{\mathrm{i} 2} \sigma_{\mathrm{it}-1}^{2}
\end{aligned}
$$

Model (8) was used to calculate abnormal share returns and was as specified by Brown and Warner (1985).

$$
\mathrm{ABSR}_{\mathrm{it}}=\mathrm{ASR}_{\mathrm{it}}-\mathrm{ESR}_{\mathrm{it}}
$$

Where

$\mathrm{ABSR}_{\mathrm{it}}=\mathrm{Abnormal} \mathrm{share} \mathrm{returns} \mathrm{of} \mathrm{company}_{\mathrm{i}}$ at time ${ }_{\mathrm{t}}$

$\mathrm{ASR}_{\mathrm{it}}=$ Actual share returns of company $_{\mathrm{i}}$ at time ${ }_{\mathrm{t}}$

$\mathrm{ESR}_{\mathrm{it}}=$ Expected share returns of company $_{\mathrm{i}}$ at time $\mathrm{t}_{\mathrm{t}}$

Under the market return model, abnormal share returns relate to the disturbance term calculated on an out of sample basis. This implies that under the null hypothesis and dependent upon market returns during the event window period, abnormal share returns have a normal distribution pattern with a zero conditional mean and conditional variance as specified in model (9). 


$$
\sigma_{\text {ABSRit }}^{2}=\sigma^{2} \varepsilon_{\text {it }}+1 / \mathrm{N}\left[1+\left[\mathrm{R}_{\mathrm{m}}-\mu_{\mathrm{m}}\right]^{2} / \sigma_{\mathrm{m}}^{2}\right]
$$

In model (9), the conditional variance of abnormal share returns has components of the disturbance variance and variance due to the sampling error in the estimation of returns on shares when there is no change in the market returns and beta coefficients.

The sampling error common among all observations during the event period results to serial correlation of abnormal share returns even under circumstances where the disturbances are independent during the entire event period. However, as the length of the event period increases, variances arising from the sampling error approach zero as the sampling error of the parameter diminishes. In this case, the variance of the abnormal share returns is $\sigma 2$ zit and the observations of the abnormal share returns become independent over time. Under the null hypothesis that the announcement of secondary equity offers does not affect share returns, the distributional properties of abnormal share returns can be applied to draw statistical inferences during the event period.

Abnormal share returns were computed for each trading day in the event period. The individual trading day's abnormal share returns were summed to compute the cumulative abnormal share returns from the beginning to the end of the event period. The cumulative abnormal share returns were computed using model (10) as specified by Brown and Warner (1985) and MacKinlay (1997).

$$
\mathrm{CABSR}=\sum \mathrm{DABSR}
$$

Where:

$\mathrm{CABSR}=$ Cumulative abnormal share returns

DABSR = Daily abnormal share returns

The cumulative abnormal share returns obtained from model (10) were averaged to obtain the average cumulative abnormal share returns. The average cumulative abnormal share returns were computed using model (11) as specified by Brown and Warner (1985) and MacKinlay (1997).

$$
\mathrm{ACABSR}=1 / \mathrm{N} * \mathrm{CABSR}
$$

Where:

ACABSR = Average cumulative abnormal share returns

$\mathrm{N}=$ Number of observations in the sample

CABSR = Daily abnormal share returns

To establish whether abnormal share returns were significant there was need to determine whether the average cumulative abnormal share returns were statistically different from zero (Medeiros \& Matsumoto, 2005). This procedure used a t test statistic and tested the null hypothesis that the average cumulative abnormal share returns were not significantly different from zero during the event period. To test the hypothesis, a critical $t$ value read from the $t$ distribution table was compared to a calculated $t$ value based on the adjusted average cumulative abnormal share returns that were derived using model (12). Model (12) referred to as the standardized residual t test, was developed by Patell (1976).

$$
\mathrm{T}_{\text {patell }}=[1 / \mathrm{N} * \mathrm{CABSR}] / \sigma_{\mathrm{ACABSR}}
$$

\subsection{Diagnostic Testing}

In this study, it was necessary to ensure that the assumptions of the classical linear regression model were not violated prior to running model (2). According to Brooks (2008), using linear regression models when the assumptions of the classical linear regression model are violated results to biased, inefficient and inconsistent parameter estimates. Five assumptions are made with regard to the classical linear regression model to demonstrate that the estimation technique, ordinary least squares has a number of desirable properties and also to ensure that hypothesis tests regarding the coefficient estimates can be validly conducted (Brooks, 2008). Consequently, the following diagnostic tests were carried out to ensure that model (2) was properly specified. These include normality (Shapiro Wilk test), heteroscedasticity (Breusch Pagan chi square test), autocorrelation (Durbin Watson test) and stationarity (Phillips Perron test).

\section{Research Findings and Discussion}

\subsection{Study Response Rate}

The sample analyzed comprised of all Nairobi Securities Exchange listed companies that had announced secondary 
equity offers namely bonus issues and rights issues between January 2006 and December 2015. During this ten-year period, a total of 41 listed companies announced a total of 80 secondary equity offers comprising of 52 bonus issues and 28 rights issues which were all covered thus translating to $100 \%$ coverage.

\subsection{Sample Characteristics}

Table 1 provides a summary of the classification of secondary equity offers according to their type and period.

Table 1. Sample charactristics

\begin{tabular}{llllll}
\hline Period & Bonus Issues & Rights Issues & Total & \% Bonus Issues & \% Rights Issues \\
\hline $2006-2010$ & 25 & 10 & 35 & $71 \%$ & $29 \%$ \\
\hline $2011-2015$ & 27 & 18 & 45 & $60 \%$ & $40 \%$ \\
\hline Total & $\mathbf{5 2}$ & $\mathbf{2 8}$ & $\mathbf{8 0}$ & $\mathbf{6 5 \%}$ & $\mathbf{3 5 \%}$ \\
\hline
\end{tabular}

Source: Research Data, 2015.

Bonus issues and rights issues comprised of $65 \%$ and $35 \%$ respectively of the total secondary equity offers announced by companies listed on Nairobi Securities Exchange during the period January 2006 to December 2015. This implied that at Nairobi Securities Exchange, companies preferred to raise equity capital through bonus issues when compared to rights issues. Bonus issues are issued free of charge as opposed to rights issues that are offered at a price consideration. In addition, listed companies opt for bonus issues as opposed to paying cash dividends, which attract withholding tax and have the effect of reducing company cash flows. Furthermore, bonus issues do not alter the shareholding structure of a company and thus have no negative dilution effect.

More listed companies announced secondary equity offers during the period January 2011 to December 2015 when compared to January 2006 to December 2011. This implied that with the passage of time, secondary equity offers became a popular means of raising equity capital by companies listed on Nairobi Securities Exchange. The popularity of rights issues increased during the period January 2011 to December 2015 because rights issues have a larger dilution effect when compared to bonus issues and thus there is a very low probability of a few hostile investors attaining controlling shareholding which they can use as a platform to launch takeover bids (Eitman, Stonehill\&Moffet, 2013).

\subsection{Diagnostic Test Results}

The results of the diagnostic tests performed were as summarized in Table 2.

Table 2. Diagnistic test results

\begin{tabular}{lll}
\hline Diagnostic Test & Value 1 & Value 2 \\
\hline Shapiro Wilk & $\mathrm{p}$ value $=0.0983$ & significance value $=0.05$ \\
\hline Breusch Pagan & $\mathrm{p}$ value $=0.3817$ & significance value $=0.05$ \\
\hline Durbin Watson & center of distribution $=2$ & test statistic $=1.92$ \\
\hline Phillips Perron & critical value $=-2.92$ & test statistic $=-7.247$ \\
\hline
\end{tabular}

Source: Research Data, 2015.

The Shapiro Wilk (1965) test was performed to test the null hypothesis that the study data was normal. Share returns reported $\mathrm{p}$ value $=0.0983>0.05$ and hence failure to reject the null hypothesis. This implied that the study data was in the order required to conduct hypothesis tests about the model parameters and tests requiring normality of the data such as $\mathrm{t}$ tests would be reliable to make statistical inferences.

The Breusch Pagan (1979) chi square test was performed to test the null hypothesis that the variance of the error terms was not heteroscedastic or not changing over time. The chi statistic of share returns reported $\mathrm{p}$ value $=$ $0.3817>0.05$ and hence failure to reject the null hypothesis. This implied that the variance of the error terms were not heteroscedastic or not changing over time thereby making the standard errors appropriate for testing the significance of the coefficients. 
The Durbin Watson (1951) test was performed to test the null hypothesis that the study data had no autocorrelation. Share returns reported test statistic $=1.92$ was within the neighborhood of its center of distribution $(\mathrm{d}=2.0)$ and hence failure to reject the null hypothesis. This implied that the error terms of the study variables were not related and the coefficients that would be obtained from the regression model would be best, linear and unbiased estimators.

The Phillips Perron (1988) test was performed to test the null hypothesis that the study data was not stationary. Share returns reported critical values $=-2.92<$ computed test statistic $=-7.247$ and hence rejection of the null hypothesis. This implied that all the study variables were stationary and thus applying the ordinary least squares regression methodology would not result to spurious regressions.

\subsection{Share Returns Before Secondary Equity Offer Announcements}

A summary of the average cumulative abnormal share returns for all secondary equity offers, bonus issues and rights issues twenty days before secondary equity offer announcements were as shown by Table 3 .

Table 3. Average cumulative abnormal share returns before secondary equity offer announcement

\begin{tabular}{llll}
\hline Metric & Bonus Issues & Rights Issues & All \\
\hline Mean & 0.004758 & 0.013031 & 0.00765 \\
\hline Standard Deviation & 0.017098 & 0.022482 & 0.01848 \\
\hline Standard Error & 0.00382 & 0.00503 & 0.00413 \\
\hline Calculated $\mathrm{T}$ & 1.2444 & 2.5920 & 1.8520 \\
\hline $\mathrm{t}_{0.05 / 2,20}$ & 2.0860 & 2.0860 & 2.0860 \\
\hline
\end{tabular}

Source: Research Data, 2015.

For bonus issues and a combination of bonus issues and rights issues (all secondary equity offers), the tabulated statistics (critical values) reported values greater than the calculated $t$ statistics, which implies that the average cumulative abnormal share returns for bonus issues and all secondary equity offers were not significantly different from zero. This was an indication that at Nairobi Securities Exchange, investors were earning normal share returns during the period twenty days before the announcement of secondary equity offers. This implied that before announcement of secondary equity offers, market share prices were not increasing significantly and as such, investors were not increasing their wealth. This was expected because there was no new information or news in the capital market with regard to companies raising capital through secondary equity offers for investors to react to.

For rights issues, the tabulated statistic (critical value) $=2.0860<$ calculated $t$ statistic $=2.5920$ which implies that the average cumulative abnormal share returns for rights issues were significantly different from zero. This was an indication that investors were earning abnormal share returns during the period twenty days before the announcement of rights issues. This implied that before announcement of rights issues, market share prices were increasing significantly and investors were increasing their wealth.

There is a time lag between the management proposition to carry out a rights issue, seeking shareholder approval during the annual or extraordinary general meetings, seeking approval from market regulators and the actual formal company announcement. Thus, there is likelihood that investors and market analysts would have prior information regarding impending rights issues, which would lead to an increase in market share prices especially for closely held shares and companies with a low free float of shares.

\subsection{Share Returns After Secondary Equity Offer Announcements}

A summary of the average cumulative abnormal share returns for all secondary equity offers, bonus issues and rights issues twenty days after secondary equity offer announcements were as shown by Table 4 .

Table 4. Average cumulative abnormal share returns after secondary equity offer announcement

\begin{tabular}{llll}
\hline Metric & Bonus Issues & Rights Issues & All \\
\hline Mean & 0.011684 & 0.023965 & 0.015982 \\
\hline Standard Deviation & 0.012654 & 0.025036 & 0.016775 \\
\hline
\end{tabular}




\begin{tabular}{llll}
\hline Standard Error & 0.002830 & 0.005600 & 0.003751 \\
\hline Calculated T & 4.1290 & 4.2810 & 4.2600 \\
\hline $\mathrm{t}_{0.05 / 2,20}$ & 2.0860 & 2.0860 & 2.0860
\end{tabular}

Source: Research Data, 2015.

For bonus issues, rights issues and all secondary equity offers, the tabulated statistics (critical values) reported values less than the calculated $t$ statistics, which implies that the average cumulative abnormal share returns for bonus issues, rights issues and all secondary equity offers were significantly different from zero. This was an indication that at Nairobi Securities Exchange, investors were earning abnormal share returns during the period twenty days after the announcement of secondary equity offers. This implied that post announcement of secondary equity offers, market share prices were increasing significantly and investors were increasing their wealth.

This further implied that secondary equity offer announcements had a positive effect on share returns and thus investors perceived the announcements to be good news and this led to an increase in share prices and share returns post announcement.

\subsection{Share Returns During the Event Period}

The three objectives of this study sought to establish the effect of secondary equity offer announcements on share returns of bonus issues, rights issues and all secondary equity offers during the event period at Nairobi Securities Exchange, Kenya. To this end, the researcher formulated three null hypotheses namely $\mathrm{H}_{01}, \mathrm{H}_{02}$ and $\mathrm{H}_{03}$ with regard to bonus issues, rights issues and all secondary equity offers:

$\mathrm{H}_{01}$ : Bonus issue announcements do not significantly affect share returns during the event period at Nairobi Securities Exchange, Kenya

$\mathrm{H}_{02}$ : Rights issue announcements do not significantly affect share returns during the event period at Nairobi Securities Exchange, Kenya

$\mathrm{H}_{03}$ : Bonus issue and rights issue announcements do not significantly affect share returns during the event period at Nairobi Securities Exchange, Kenya

All the three hypotheses were tested using the $t$ test by comparing the calculated $t$ value derived using model (12) and a critical $t$ value read from the $t$ distribution tables. A summary of the average cumulative abnormal share returns for bonus issues, rights issues and a combination of bonus issues and rights issues during the event period are as shown by Table 5 .

Table 5. Average cumulative abnormal share returns after secondary equity offer announcement

\begin{tabular}{llll}
\hline Metric & Bonus Issues & Rights Issues & All \\
\hline Mean & 0.0085 & 0.0190 & 0.0122 \\
\hline Standard Deviation & 0.0152 & 0.0241 & 0.0179 \\
\hline Standard Error & 0.0023 & 0.0037 & 0.0027 \\
\hline Calculated T & 3.603 & 5.066 & 4.379 \\
\hline $\mathrm{t}_{0.05 / 2,41}$ & 2.021 & 2.021 & 2.021 \\
\hline
\end{tabular}

Source: Research Data, 2015.

A positive mean average cumulative abnormal share return for bonus issues, rights issues and all secondary equity offers is an indication that during the periods twenty days before announcement and twenty days after announcement of secondary equity offers, the market prices of shares were on average increasing. Rights issues witnessed a higher average cumulative abnormal share return when compared to bonus issues.

For bonus issues, rights issues and all secondary equity offers, the tabulated statistics (critical values) reported values less than the calculated t statistics, which implies that the average cumulative abnormal share returns for bonus issues, rights issues and all secondary equity offers were significantly different from zero. Therefore, the study rejected the null hypotheses $\mathrm{H}_{01}, \mathrm{H}_{02}$ and $\mathrm{H}_{03}$ that secondary equity offer announcements do not affect share returns of bonus 
issues, rights issues and all secondary equity offers respectively during the event period at the $95 \%$ confidence level or $5 \%$ level of significance.

This was an indication that at Nairobi Securities Exchange, investors were earning abnormal share returns during the secondary equity offer period, which implied that market share prices were increasing significantly and investors were increasing their wealth. This further implied that secondary equity offer announcements had a positive effect on share returns and thus investors at Nairobi Securities Exchange perceived secondary equity announcements to be good news, which led to an increase in share prices and share returns.

From a theoretical perspective, the study findings were consistent with the arguments of the agency cost theory and static trade off theory, which hypothesize that secondary equity offer announcements have a positive effect on share returns. However, the study findings were inconsistent with the arguments proposed by the efficient market hypothesis and the random walk theory that hypothesize a neutral relationship between secondary equity offer announcements and share returns. The study findings were also inconsistent with the postulations of the information asymmetry theory and adverse selection principle, which hypothesize a negative relationship between secondary equity offer announcements and share returns.

From an empirical viewpoint, the study results were similar to Kamanja (2014), Kithinji et al. (2014) and Ndungu (2014) who reported positive share returns at Nairobi Securities Exchange and Miglani (2011), Huang (2012) and Ramesh and Rajumesh (2014) who reported positive share returns at Bombay Stock Exchange, Shanghai Stock Exchange and Colombo Stock Exchange respectively. However, the study findings differed from Hess and Frost (1982) who observed neutral share returns and Lerskullawat (2011) who reported negative share returns at New York Stock Exchange and Stock Exchange of Thailand respectively. The study findings were also different from Ogada (2014) and Mariko and Theuri (2016) who observed neutral share returns and Olesaaya (2010) and Otieno (2014) who reported negative share returns at Nairobi Securities Exchange.

\section{Conclusion and Recommendations}

\subsection{Conclusion}

Before announcement of secondary equity offers, investors on the Nairobi Securities Exchange were earning normal share returns, market share prices were not increasing significantly and as such, investors were not increasing their wealth. After announcement of secondary equity offers, investors on the Nairobi Securities Exchange were earning above normal share returns, market share prices were increasing significantly and as such, investors were increasing their wealth. During the event window period, investors on the Nairobi Securities Exchange were earning above normal share returns, market share prices were increasing significantly and as such, investors were increasing their wealth.

The study therefore study concluded that at Nairobi Securities Exchange, secondary equity offer announcements had a significant and positive effect on share returns. Investors perceived secondary equity offer announcements to be good news because during the event window period, market share prices increased significantly, share returns were positive and investors increased their wealth. During the event period, rights issues realized higher share returns when compared to bonus issues. Therefore, investors who participated in rights issues earned higher share returns when compared to investors who participated in bonus issues.

\subsection{Recommendations}

This study recommends management of Nairobi Securities Exchange listed companies to raise capital through secondary equity offers, as this will result to an increase in share prices and the market value of companies. Investors are also encouraged to invest in secondary equity offers because they will earn positive returns and increase their wealth. Existing shareholders are discouraged from renouncing their rights because they will forego high share returns witnessed during the rights issue period. The Capital Markets Authority and Nairobi Securities Exchange should encourage listed companies to raise equity through secondary equity offers because this will have the dual effect of increasing a company's market value and increasing investor wealth, which is advantageous to both management and investors.

\subsection{Study Limitations and Suggestions for Future Research}

Secondary data is prone to errors and biases such as sampling and non sampling errors, errors that invalidate the data, errors that require data reformulation and errors that reduce reliability. Saunders, Lewis and Thornhill (2009) point out those errors in secondary data can lower the reliability and validity of a study's findings and therefore researchers should carefully handle secondary data. This study relied on secondary data and addressed this challenge by using 
secondary data from reliable sources such as the Nairobi Securities Exchange, Capital Markets Authority and audited financial statements. This study can be extended to other securities exchanges in East Africa such as Dar Es Salaam Stock Exchange, Rwanda Stock Exchange and Uganda Securities Exchange. Researchers can consider employing the buy and hold methodology to assess the long term affects of secondary equity offer announceents on share returns.

\section{References}

Agarwal, A., \& Mohanty, P. (2012). The Impact of Rights Issues on Stock Returns in India. Asia Pacific Finance and Accounting Review, 1(1), 5-16.

Akerlof, G. A. (1970). The Market for Lemons: Quality Uncertainty and the Market Mechanism. Journal of Economics, 84, 488-500. https://doi.org/10.2307/1879431

Berk, J., \& De Marzo, P. (2013). Corporate Finance (3rd ed.). New York: Prentice Hall.

Bollerslev, T. (1986). Generalized Autoregressive Conditional Heteroscedasticity. Journal of Econometrics, 3(3), 307-327. https://doi.org/10.1016/0304-4076(86)90063-1

Brooks, C. (2008). Introductory Econometrics for Finance. Cambridge: Cambridge University Press. https://doi.org/10.1017/CBO9780511841644

Brown, S., \& Warner, J. (1985). Using Daily Stock Returns: The Case of Event Studies. Journal of Financial Economics, 14(1), 3-31. https://doi.org/10.1016/0304-405X(85)90042-X

De Angelo, H., De Angelo, L., \& Stulz, R. M. (2009). Seasoned Equity Offerings, Market Timing and Corporate Life Cycle. Journal of Financial Economics, 95(3), 275-295. https://doi.org/10.1016/j.jfineco.2009.11.002

Durbin, J., \& Watson, G. S. (1951). Testing for Serial Correlation in Least Squares Regression. Biometrika, 38(2), 159-71. https://doi.org/10.1093/biomet/38.1-2.159

Eitman, D. K., Stonehill, A. I., \& Moffet, M. H. (2013). Multinational Business Finance. New York: Prentice Hall.

Engle, R. F. (1982). Autoregressive Conditional Heteroscedasticity with Estimates of the Variance of United Kingdom Inflation. Econometrica, 50(4), 987-1007. https://doi.org/10.2307/1912773

Fama E, F., \& French, K. (1992). The Cross Section of Expected Stock Returns. Journal of Finance, 47, 427-465. https://doi.org/10.1111/j.1540-6261.1992.tb04398.x

Fama, E. (1998). Market Efficiency, Long Term Returns and Behavioral Finance. Journal of Financial Economics, 49(3), 283-306. https://doi.org/10.1016/S0304-405X(98)00026-9

Goetzmann, W. N. (2000). An Introduction to Investment Theory (5th ed.). Yale: Ibbotson Associates.

Hess, A. C., \& Frost, P. A. (1982). Tests for Price Effects of New Issues of Seasoned Securities. Journal of Finance, 37(1), 11-25. https://doi.org/10.1111/j.1540-6261.1982.tb01092.x

Huang, Z. (2012). Seasoned Equity Offerings in China. Doctor of Philosophy Dissertation. Retrieved from http://eprints.soas.ac.uk/13813

Jensen, M. C., \& Meckling, W. H. (1976). Managerial Behavior, Agency Costs and Ownership Structure. Journal of Financial Economics, 3(4), 305-360. https://doi.org/10.1016/0304-405X(76)90026-X

Kamanja, B. (2014). The Effects of Bonus Issue Announcements on Share Prices of Commercial Banks Listed on Nairobi Securities Exchange. Unpublished Dissertation. University of Nairobi, Kenya.

Kerlinger, F. H., \& Lee, H. B. (2000). Foundations of Behavioral Research. New York: Harcourt College Publishers.

Kirui, E., Wawire, H. W., \& Onono, P. O. (2014). Macroeconomic Variables, Volatility and Stock Returns: A Case of Nairobi Securities Exchange Kenya. International Journal of Economics and Finance, 6(8), 214-228. https://doi.org/10.5539/ijef.v6n8p214

Kithinji, J. G., Oluoch, W., \& Mugo, W. (2014). The Effect of Rights Issue on Firm Share Performance at Nairobi Securities Exchange. Research Journal of Finance and Accounting, 5(4), 76-84.

Kraus, A., \& Litzenberger, R. H. (1973). A State Preference Model of Optimal Financial Leverage. Journal of Finance, 911-922. https://doi.org/10.1111/j.1540-6261.1973.tb01415.x

Lerskullawat, P. (2011). Seasoned Equity Offerings in an Emerging Market: Evidence from Thailand. Unpublished Dissertation. University of Birmingham, United Kingdom.

MacKinlay, A. C. (1997). Event Studies in Economics and Finance. Journal of Economic Literature, 35, 13-39. 
Mariko, J. B., \& Theuri, J. M. (2016). Effect of New Information from Rights Issue Announcements on Share Prices of Firms Listed on Nairobi Securities Exchange. American Journal of Finance, 1(4), 54-70.

Mbui, A. L. (2016). Effect of Bonus Issue Announcements on Share Returns of Companies Listed on Nairobi Securities Exchange. Unpublished Dissertation. University of Nairobi, Kenya.

Medeiros, O. R., \& Matsumoto, A. S. (2005). Brazilian Market Reaction to Equity Issue Announcements. Brazilian Administration Review, 2, 35-46. https://doi.org/10.1590/\$1807-76922005000200004

Meucci, A. (2010). Linear Versus Compounded Return Calculations: Common Pitfalls in Portfolio Management. GARP Risk Management, 40-43.

Miglani, P. (2011). An Empirical Analysis of Impact of Right Issues in the Indian Listed Companies. Journal of Arts, Science and Commerce, 2, 169-176.

Myers, S. C. (1984). The Capital Structure Puzzle. Journal of Finance, 39, 575-592. https://doi.org/10.1111/j.1540-6261.1984.tb03646.x

Myers, S. C., \& Majluf, N. S. (1984). Corporate Financing and Investment Decisions. Journal of Financial Economics, 13(2), 187-221. https://doi.org/10.1016/0304-405X(84)90023-0

Ndegwa, J. N., \& Kiweu, J. M. (2013). Is There Profit from Bonus Share Announcements in Nairobi Securities Exchange?. Research Journal of Finance and Accounting, 4(8), 10-19.

Ndungu, P. N. (2014). The Effect of Rights Issue Announcement on Share Prices of Companies Listed at Nairobi Securities Exchange. Unpublished Dissertation. University of Nairobi, Kenya.

Ogada, A. (2014). Impact of Rights Issues of Share Returns of Firms Listed on the Nairobi Securities Exchange. Unpublished Dissertation. United States International University, Kenya.

Olesaaya, E. (2010). The Effects of Rights Issue on Stock Returns. Case study of Companies Listed at Nairobi Securities Exchange. Unpublished Dissertation. University of Nairobi, Kenya.

Onclin, N. (2014). An Investigation to the Announcement Impact from Right Issues on Stock Prices in the Dutch Capital Market. Unpublished Dissertation. University of Twente, Netherlands.

Otieno, D. (2014). The Effects of Rights Issue Announcements on Stock Returns of Firms Listed on Nairobi Securities Exchange. Unpublished Dissertation. University of Nairobi, Kenya.

Owusu, N. V., \& Kuwornu, J. K. (2011). Analyzing the Effect of Macroeconomic Variables on Stock Market Returns: Evidence from Ghana. Journal of Economics and International Finance, 3(11), 605-615. Retrieved from http://www.academicjournals.org/JEIF

Patell, M. J. (1976). Corporate Forecasts of Earnings per Share and Stock Price Behavior: Empirical Tests. Journal of Accounting Research, 14(2), 246-256. https://doi.org/10.2307/2490543

Phillips, P. B., \& Perron, P. (1988). Testing for a Unit Root in Time Series Regression. Biometrika, 75, 335-346. https://doi.org/10.1093/biomet/75.2.335

Ramesh, S., \& Rajumesh, S. (2014). Information Content of Right Issue Announcements: A Study of Listed Companies in Colombo Stock Exchange of Sri Lanka. Research Journal of Finance and Accounting, 5(5), 154-162.

Reilly, F. K., \& Brown, K. C. (2011). Investment Analysis and Portfolio Management. Orlando: Harcourt Press.

Saunders, M., Lewis, P., \& Thornhill, A. (2009). Research Methods for Business Students. Harlow: Prentice Hall.

Shapiro, S., \& Wilk, M. B. (1965). An analysis of the Variance Test for Normality. Biometrica, 52(3), 591-611. https://doi.org/10.1093/biomet/52.3-4.591

Tepe, M. (2012). Market Reaction to Rights Offering Announcements in the Turkish Stock Market. Unpublished Dissertation. Middle East Technical University, Turkey.

Velayutham, E. (2015). Shareholder Wealth Effects of Rights Issues and Bonus Issues: Evidence From Sri Lanka. International Journal of Accounting and Business Finance, 2, 1-13.

Wilcox, J. W., \& Fabozzi, F. J. (2013). Financial Advice and Investment Decisions (1st ed.). New York: Wiley.

Wright, R. E., \& Sylla, R. (2013). Corporate Governance and Stockholder/Stakeholder Activism in the United States. Daedalus, 142(2), 1790-1860. 